JeDEM 10(1): 50-81, 2018

ISSN 2075-9517

http://www.jedem.org

\title{
Revisiting the Open Government Phenomenon. A Meta-Analysis of the International Literature
}

\section{J. Ignacio Criado*, Edgar Alejandro Ruvalcaba-Gómez*, Rafael Valenzuela-Mendoza**}

* Department of Political Science and International Relations, Universidad Autónoma de Madrid, Spain; ignacio.criado@uam.es, edgar.ruvalcaba@inv.uam.es

** Social Science and Public Administration Institute (ICSA), Autonomous University of Juarez City (UACJ), ICSA, México; rafael.valenzuela@uacj.mx

Abstract: The Open Government (OG) concept is maturing and moving toward its consolidation as a new field of multidisciplinary knowledge with its own dynamics. However, little is known about how it is developing that path, if it is really generating its own characteristics and what its scope is in terms of the creation of an academic community. This article conducts a systematic review or meta-evaluation of the literature on OG for 5 years (2011 to 2015) from the three magazines most recognized for their production and quality of content on the theme: Government Information Quarterly, Information Polity and eJournal of eDemocracy and Open Government. This article analyzes 189 articles, classified into different categories that try to answer three research questions: How is the OG analyzed? (Study Design, Research Techniques, Methodological Approach) Where is the OG analyzed? (University Departments, Host Country of the Universities and Institutions, Level of Government, Analyzed Country/Areas) What are the most analyzed topics and the most prominent concepts in the study of OG? (Main Topic, Keywords). Article data reveal the key features of OG analysis: few quantitative and explicative-correlational studies, a strong focus on the countries of the Anglo-American area, and very diverse interests ranging from open data, e-government and social media to coproduction. In addition, it can be established to what extent a scientific community around OG has been created. Some conclusions about the development of OG in coming years are made.

Keywords: Transparency, participation, collaboration, meta-analysis, e-government, open data, research techniques.

Acknowledgement: This work was partially supported by the research program S2015/HUM3466 NEW TRUST-CM (Comunidad de Madrid and ESF) and by Autonomous University of Juarez City and Mexico's National Council of Science and Technology through the open government organisational dimension project (Conacyt/CB/257040). 


\section{Introduction}

In recent years the term Open Government (OG) has attracted the academic attention of a growing number of researchers from different disciplines, albeit with the special interest of e-government scholars. This is reflected in the publicity being given to this issue through articles, books, conferences and even organizations that are constituted using this notion. This article aims to categorize the orientation that the academic study of OG is taking and to foster a debate on the topics that are listed on the construction of an academic community oriented to the study of this phenomenon at an international level. This asks for a systematic review (meta-analysis) of the OG articles published in leading academic journals in recent years. Generally speaking, several authors (Criado et al., 2013; Ganapati and Reddick, 2012; Lathrop and Ruma, 2010; McDermott, 2010; Ruvalcaba-Gomez et al., 2018) assume that the OG concept denotes a relationship of mutual collaboration between citizens and the state, where civil society has a leading role due to the availability and application of new social technologies. This facilitates multiple interactions between social and state actors, and it translates into more transparent, participatory and collaborative links (Criado et al. 2013; Ganapati and Reddick, 2012; Gonzalez-Zapata and Heeks 2015; Lathrop and Ruma, 2010; Lee and Kwak, 2012; McDermott, 2010; Meijer et al. 2012). However, the realization of the principles of OG, as well as the path to be taken by governments and public management models, is not something that generates unanimity.

On the one hand, there are some who consider that the OG is a way of development of the electronic government (EG) by other means. After the rise of the EG in public administration from the turn of the century, especially to improve the internal management through the digitalization of procedures and communication with citizens through web pages, several studies (Abu-Shanab, 2015; Criado, 2013; Gil-Garcia et al., 2017; Meijer et al., 2012; Scholl et al. 2012; Wijnhoven et al. 2015) have continued to stress the potential of information and communication technologies (ICT) to transform governance schemes, improve the civil service and develop in the public sector a new relationship model towards citizens. To some extent, this process has been accelerated since 2010 with the incorporation into the public sector of a new generation of social, collaborative and open technologies (web 2.0 tools: apps, digital social networks, geolocation tools, open data web portals, etc.), which are focused on implementing more fundamental political and administrative changes. Therefore, one may think about a new form of governance based on transparency, participation and collaboration; dimensions that led to generalizing that the OG concept was a new model of socio-political interaction with impact on good governance and improvement on the innovativeness of public administrations (Abu-Shanab, 2015; Criado, 2013; Criado and Ruvalcaba-Gomez 2018; Ganapati and Reddick, 2012; Gascó, 2015; Grimmelikhuijsen, 2012, Lathrop and Ruma, 2010; Meijer et al., 2012; Noveck, 2017; Scholl et al. 2012; Wijnhoven et al. 2015). 
The abovementioned has an important political and social relevance related to the study of this emerging paradigm in the studies of government and public administration. The constant endeavor to have more efficient governments is not the only reason for the study of the OG; this term also implies a deepening of democratic principles and legitimacy of governments, which implies a challenge to restore public administrations as pluralistic institutions operating close to society. Consequently, the OG is an aspiration that comes from civil society, to a lesser extent than the governments themselves. Under this new paradigm, the institutional power at different levels promotes co-production of public services and the solving of public problems using collaborative approaches with the social sectors involved.

Then, this research aims to study what the situation of the international research surrounding OG is, and discover the characteristics of the emerging academic community that is working with that concept. This research has been developed from a meta-analysis of a total universe of 186 academic articles on OG, published in the three academic journals with the highest quality and impact within the scope of e-government between 2011 and 2015. The three magazines chosen present a high production of articles in relation to OG: Government Information Quarterly, Information Polity, and eJournal of eDemocracy and Open Government. Specifically, the selection of articles was performed based on their direct connection to the term OG in the title, keywords or abstract, or in relation to the content of the text.

The meta-evaluation is a technique that quantitatively combines the data of each article, to standardize information and make it comparable. The field work consisted of collecting data from the articles, encoding and interpreting them using a descriptive design, and whose results can be used as input for prospective studies and for creating scenarios (Attard et al., 2015; Bannister and Connolly, 2014; Dekker and Bekkers, 2015; Meijer and Bekkers, 2015; Rana and Dwivedi, 2015; Sivarajah et al., 2015; Tranfield et al., 2003; Webster and Watson, 2002). This research study followed several steps: definition, search, selection, analysis and presentation (Wolfswinkel, Furtmueller, and Wilderon, 2013), and had a significant background in the field of innovation in government and public administration, where topics such as e-participation and e-government are included (Estevez and Janowski, 2013; Janowski, 2015; Luna-Reyes and Gil-Garcia, 2014; Medaglia, 2012, Sæbø et al 2008; Scholl, 2009). Thus, it has been possible to have a base of analysis that allows understanding of the current situation of the OG and a consideratio $n$ ofits development in future research studies.

The study aims to contribute to the work of the emerging academic community that is analyzing the concept of OG internationally. Specifically, the analysis answers the following research questions: How is the OG analyzed? Where is the OG analyzed? What are the most analyzed topics (transparency, participation, collaboration) and the most prominent concepts in the study of OG? The dimensions and categories for the analysis of the articles are divided according to the three research questions. The first deepens into the type of research design, 
research techniques used or methodological approach implemented. In the second case, the departments or academic centers of origin of the researchers, the host country of universities and/or institutions, the level of government under study and the referenced country/area are observed. Finally, the analysis is completed with a comparative study of the main topics of the articles and the keywords.

The rest of the article is organized as follows. The next section addresses some of the main approaches to the $\mathrm{OG}$ and some ideas about its evolution arise, considering its recent conceptualization based on three topics: transparency, participation and collaboration. The third section of this article presents the methodological and analytical framework, in which it states the dimensions and categories with which the study is developed, how the research questions were created and how the articles analyzed were selected. The fourth section presents the analysis of the data, using descriptive statistics that allow to analyse the academic state-of-the-art of OG. The fifth section discusses the results, presenting ideas on the development of OG. Finally, the sixth section presents the findings of the study as well as its limitations, also drawing a picture of future research around OG.

\section{Conceptual framework of the study}

\subsection{Background of the open government concept. New wine in old bottles?}

The term OG has very notorious history in the international debate on transparency and access to public information. Chapman and Hunt (1987), locate it in the early 1970's in the British political context. Clarke and Francoli (2014) and Valenzuela (2013) highlight the work done by Parks in 1957 entitled "The Open Government Principle: Applying the Right to Know Under the Constitution," in which he addresses the access and freedom of public information in the context of the model of government accountability. These initial approaches focused on various issues related to the secrecy of governmental institutions and efforts to "open windows" into the public sector to to allow citizen scrutiny in order to reduce obscurantism (Janssen and van den Hoven, 2015; Zuiderwijk et al. 2015), which led to the extension of legislation on the right of access to public information and the incorporation of mechanisms to improve accountability. Schnell's study (2017) shows the factors that stand out in the relationship between transparency policies and corruption. Therefore, these records show the interest in the study of OG from the angle of information to generate public value, or combat opacity to prevent misuse of the discretion of the government.

More recently, the concept OG has been revitalized thanks to political and institutional backing in different contexts. An important milestone in the revitalization of the OG concept is highlighted in the "Memorandum for Transparency and Open Government" first antecedent, adopted under the Obama administration (January 21, 2009). From then on, this subject is incorporated as a top- 
level political priority around three principles: transparency, participation, and collaboration. The actions to be developed along these lines were raised as a new way to approach citizens, a revolution in how to use information from public administrations, or even, a governmental platform in which citizens become the protagonists of democracy (Lathrop and Ruma, 2010). Along the same lines, we note as the next milestone, the efforts of the first prime ministers Brown and Cameron in the UK, as promoters of policies of access to information, with the aim of showing that public and easily accessible information would help citizens make better decisions and suggestions on government policies.

A third precedent is located in international organizations, which have contributed to putting the debate on OG, as an important issue, in the public agenda. The OECD (2011) has defined the OG as that characterized by the transparency of its actions, the accessibility of citizens to their services and information, and government receptivity to new ideas, demands and needs. Meanwhile, in a publication of the Inter-American Development Bank (IDB), Lopez (2014, p.2) mentions that the OG "is that which practices and promotes transparency and access to information, civic participation and collaboration between multiple actors in both public policy creation and service delivery". In addition, some of these international organizations have created reflection units or centers through which governments are supported to promote public policy initiatives with this new direction.

The fourth OG precedent refers to the creation of the Open Government Partnership (OGP). The OGP is a multilateral international organization, founded in 2011, and has managed to recruit 75 countries, in order to promote concrete commitments of public policy, thus, it represents the avant-garde organization for international promotion of OG practices based on the three mentioned areas (transparency, participation and collaboration) as well as other principles that are evolving. Consequently, it can be noted that there has been an international trend that has proven successful in recent years: of setting the OG in front of the international public agenda of innovation focusing on transparency, participation and collaboration of governments and public administrations. Even recently, the impact of the OG has been studied as a movement that has been reformist (Piotrowski, 2017), which has transformed the government system significantly.

\subsection{Open government today: Conceptual diversity, maturity models and information and communication technologies}

Nowadays, we find different conceptions about OG, so it is an emerging term. First, it must be noted that the OG should be understood as more than transparency. Transparency is not enough to achieve open governments since it is necessary that the incentives for participation work so as to achieve collaboration between the government and the organized civil society. In the words of Meijer, Curtin and Hillebrandt (2012, p11) "open government is not only about openness in informational terms but also about in interactive terms". Thus, these authors describe the OG as 
a matter of vision in government transparency and citizen voice in public policy processes. This may lead to understand the OG as a management model based on transparency, participation and collaboration.

Within OG, converge various topics of public management such as transparency, accountability, open access to public data, guarantee of the right to information, the protection of private data and mechanisms for citizen participation, among other topics.

On the one hand, we could say that e-government does not transform the values of society, but it makes life easier for citizens. On the other hand, when we talk about OG we are talking primarily of values - we mean rethinking administrations and governments, its vision and operational categories.

Some authors mention that the OG is a developing subject and poorly researched (Lee and Kwak, 2012; Scholl et al. 2012). However some studies include a more complex conceptualization where many of the studies take three pillars of OG; transparency, participation and collaboration (Abu-Shanab, 2015; Criado, 2013; Ganapati and Reddick, 2012; Lathrop, D, and Ruma, L, 2010; Lee and Kwak, 2012).

The link between OG and ICT is an ongoing debate. While the relationship with GE is clear, opinions differ on the role of the new wave of innovation involving social technologies. In this sense, Criado (2013) mentions that "the recent resurgence of open government is tied to the existence of new technological tools 2.0, which allow a qualitative leap in the previous contents of the concepts of transparency, participation and collaboration." This does not refer to the OG as just technology, this refers to technological new dynamics that allow the emergence of collaborative values, new participatory dynamics and a new centrality of transparency in public discourse.

OG is the construction of a more open society, where information is distributed and where the generation of social value is the basis to get a better quality of life for all citizens; this path involves innovation in the public sector and changes in government policies.

The three topics of OG: transparency, participation and collaboration are constantly being rethought and conceptualized, and these are broadly defined and even often confused with one another, especially participation and collaboration. But in practice, these principles are related actions that allow their operationalization. After the memorandum of President Obama, several studies within the OG have been concerned with these three topics. (Abu-Shanab, 2015; Lathrop and Ruma, 2010; Lee and Kwak, 2012; Meijer et al. 2012).

OG's relationship with ICT is a constant issue in dispute. While the relationship with EG is clear, opinions differ on the role of the new wave of innovation involving social technologies. In 
this sense, Criado (2013) mentions that "the recent resurgence of open government is tied to the existence of new technological tools related to Web 2.0, which allow a qualitative leap in the previous contents of the concepts of transparency, participation and collaboration". The above does not state that the OG is only technology but that the new technological dynamics allow the emergence of the collaborative values of the web 2.0, renovated participative dynamics and a new centrality of transparency in public discourse. Along the same lines, Gascó (2014) indicates that the OG refers to democratization, sharing, collaboration, and the development of a better system. So it refers to the building of a more open society, where information is distributed and where the generation of social capital is the basis for a better quality of life for all, as developed in terms of innovation in the public sector and government policies.

\section{Methodological and analytical framework of the study}

In order to explore and analyze the path of the OG, this section shows the methodology used as well as the analytical framework of the research. In particular, it poses the research questions, it establishes dimensions and categories of analysis, and it explains data selection. The article adopts the methodological technique of meta-analysis to process the literature review (Attard et al 2015; Dekker and Bekkers, 2015; Meijer and Bekkers, 2015; Tranfield et al 2003; Webster and Watson, 2002; Wolfswinkel et al. 2013), analyzing a selection of articles published on OG in some of the leading academic journals about EG, in order to deepen and categorize research conducted in recent years in relation to the concept of OG. This is linked to the formulation of research questions, the classification of a series of categories that have guided the analysis of the contents of the journals, as well as a justification for the selection of items.

\subsection{Research questions}

To continue, this intends to present the research questions that guide this article. To begin with, there is a general issue, which this article does not pretend to solve completely, and that is whether or not it is possible to identify the existence of a scientific community around the concept of OG. Along with that general issue which is discussed qualitatively, three questions guide this work, which will be answered through the quantitative analysis of this article:

Research Question 1 (RQ1). How is the OG being analyzed (study design, research techniques and methodological approaches)?

Research Question 2 (RQ 2). Where is the OG being analyzed (researcher's departments or academic centers of origin, the host country of the universities and/or institutions, the level of government under study and referenced country/area)? 
Research Question 3 (RQ 3). What are the most analyzed topics and the most prominent concepts in the study of OG (transparency, participation and collaboration, and keywords)?

The focus of these research questions arises from the need to deepen the knowledge about the epistemic community working on OG internationally. First there is an interest in issues related to the type of analysis that researchers linked to this subject are conducting (Q1), so it reviews issues such as study design, research techniques and methods applied. Second, it deals with issues of geographical location and levels of government of interest in the research conducted (Q2), so that it considers issues such as researchers' academic departments of origin, as well as the respective countries, levels of government and countries of the governments and public administrations involved in the study. Third, it considers reference terms associated with the object of study (Q3), so that it analyzes the issues (transparency, participation and collaboration) and the most used keywords in articles by those who work around OG.

\subsection{Sample selection of the articles analyzed}

As already mentioned, the methodological strategy is based on a meta-analysis of academic articles whose central axis is OG. ${ }^{1}$ Apart from considering the three journals with extensive academic production on OG, we considered some other characteristics of publications: the journal GIQ is within the Social Sciences Citation Index (SSCI) belonging to the platform "Web of Science", also GIQ is in the first group of quality within Scimago Journal \& Country Rank of Scopus database. Similarly, the journal IP has the best quality of publications considered in the SSCI. Thus both journals (GIQ and IP) are positioned as high-impact publications and high quality.

Meanwhile JeDEM is a recently created academic journal with a strong orientation on OG. The publication has high quality standards and is indexed in databases such as EBSCO, DOAJ, Google scholar, and the Public Knowledge Project. Thus, JeDEM, the first that specifically includes the concept of OG in its title is and one of the leaders in the field, is included.

In addition, it is these three journals of the highest quality which produce an increased number of articles on OG internationally. The sample of articles covers the period from January 2011 to December 2015. We took the year 2011 as the start of the analysis period because this year there is a disruptive increase in the publication of academic articles that use the term "open government". Also another reason that justifies the analysis since 2011 is the emergence of the Open Government

\footnotetext{
${ }^{1}$ Specifically, the sample analyzed is based on a selection of articles from the three scientific journals with the greatest impact in the field of social sciences related to OG and that have published more articles on the subject of OG from 2011 to 2015: Government Information Quarterly (GIQ) and Information Polity (IP). Together with them, the eJournal of eDemocracy and Open Government (JeDEM) is analyzed. These journals have been selected, among other potential and important outlets, because they include an extensive number of articles on the topic, which is paramount to forge a coherent discourse among the scholars involved in the conceptual conversation about OG.
} 
Partnership, which has undoubtedly been the most important international organization in the field. In this sense, we can infer that since 2011 the OG has become a trend in public and academic sectors. We consider five years for the analysis (until 2015). However, in future studies it will be important to update the analysis with subsequent years.

To select the articles from each journal, all articles published on OG by journals in the aforementioned period were taken into account. After the selection and filter process, the sample taken for the analysis was a total of 189 articles of the three journals mentioned, which are: 101 of GIQ, 39 of IP, and 49 of JeDEM. The selection of items was filtered based on a thorough review mainly of the full content of the articles, and assisted with titles, keywords and abstracts, following the guidelines of other previous meta-analyzes on related subjects (Hartley and Kostoff, 2003; Medaglia, 2012; Scholl, 2009; Susha and Grönlund, 2012). Thus, and given the multiple meanings of the concept of OG, it was possible go deeper and to be more analytical in selecting articles, beyond a selection based only on concepts mentioned explicitly in the abstract or keywords. In other words, this comprised related issues and the intentionality directly linked to OG, which implied reading the contents of every article.

\subsection{Analytical strategy}

With the purpose of categorizing and dimensioning the articles as the object of analysis, an organized data base was built based on a number of dimensions. Considering the research questions, as well as several features related to the type of research conducted in the articles, it defines the categories of analysis of each of the units (articles) in order to explore their content more deeply.

Table 1. - Analytical strategy of the study

\begin{tabular}{|c|c|c|}
\hline $\begin{array}{l}\text { Research } \\
\text { questions and } \\
\text { dimensions }\end{array}$ & Variables & Indicators \\
\hline \multirow{2}{*}{$\begin{array}{l}\text { (RQ 1) } \\
\text { How is the OG } \\
\text { analyzed? } \\
\text { Methodological } \\
\text { dimension }\end{array}$} & Study design & $\begin{array}{l}\text { - Normative } \\
\text { - Exploratory-descriptive } \\
\text { - Correlational-explanatory } \\
\text { - Meta-analysis }\end{array}$ \\
\hline & Research techniques & $\begin{array}{l}\text { - Documentary analysis } \\
\text { - Questionnaires } \\
\text { - Interviews } \\
\text { - Observations } \\
\text { - Focus groups } \\
\text { - Delphi Method }\end{array}$ \\
\hline
\end{tabular}




\begin{tabular}{|c|c|c|}
\hline & & - Without techniques \\
\hline & Methodological approach & $\begin{array}{l}\text { - Qualitative } \\
\text { - Quantitative } \\
\text { - Mixed } \\
\text { - Without methodology }\end{array}$ \\
\hline $\begin{array}{l}\text { (RQ2) Where is } \\
\text { the OG analyzed? } \\
\text { Community } \\
\text { dimension }\end{array}$ & University departments & $\begin{array}{l}\text { - Law } \\
\text { - Public Administration } \\
\text { - Political Sciences } \\
\text { - Sociology } \\
\text { - Economy } \\
\text { - Computer science } \\
\text { - Library studies } \\
\text { - Communication } \\
\text { - Journalism } \\
\text { - Information Systems } \\
\text { - Humanities } \\
\text { - Do not show }\end{array}$ \\
\hline & $\begin{array}{l}\text { Host country of the } \\
\text { universities and } \\
\text { institutions }\end{array}$ & - Host countries of the universities \\
\hline & Level of government & $\begin{array}{l}\text { - Local-municipal } \\
\text { - Regional-state } \\
\text { - National-federal } \\
\text { - Supranational } \\
\text { - More than one level } \\
\text { - Without a defined level }\end{array}$ \\
\hline & Analyzed Country/Areas & $\begin{array}{l}\text { - Countries that are the subject of } \\
\text { study at any level of government. }\end{array}$ \\
\hline $\begin{array}{l}\text { (RQ3) What are } \\
\text { the most } \\
\text { analyzed topics } \\
\text { and the most } \\
\text { prominent }\end{array}$ & Main topic & $\begin{array}{l}\text { - Transparency } \\
\text { - Participation } \\
\text { - Collaboration } \\
\text { - Mixed }\end{array}$ \\
\hline $\begin{array}{l}\text { concepts in the } \\
\text { study of OG? }\end{array}$ & Keywords & $\begin{array}{l}\text { - All the keywords presented in the } \\
\text { articles }\end{array}$ \\
\hline
\end{tabular}




\begin{tabular}{|l|l|l|}
\hline $\begin{array}{l}\text { Conceptual } \\
\text { dimension }\end{array}$ & & \\
\hline
\end{tabular}

First, within the study design variable, four categories were established for the articles (Normative, Exploratory-descriptive, explanatory-correlational and Meta-analysis). This first categorization intends to define under what theoretical perspective the article is constructed, and its purpose, from the point of view of building the theory or the normative scope, descriptive or explanatory, of its conclusions. Within the normative category, there is a lack of scientific probative method, and the articles are aimed at a theoretical debate on OG or one of its topics. The exploratory-descriptive research design are those that are used for conducting research for the first time or to reflect descriptive statistical results. They are also used to identify a problem and describe the facts as they are observed. Explanatory studies seek to establish inferences, establishing cause-effect within the object of study. And those studies that analyze a series of research studies on a topic, evaluating their content to generate conclusions, theories and analytical frameworks, are incorporated in the category of meta-analysis.

The variable research techniques seek to classify the articles according to the methodological and systematic procedures that oversee operationalizing and implementing research methods to gather information. The categories: documentary analysis, questionnaires, interviews, observations, focus groups, Delphi method, and articles presenting absence of research techniques were included. It is noteworthy that in the "documentary analysis" all institutional documents were considered, such as regulations, laws, reports and plans; also documents of a normative character linked to academic publications, usually used in systematic literature review, as in the case of this article. As it is logical to assume, in this classification an $\mathrm{N}$ higher (297 techniques) than the number of articles (189) was obtained because some studies show more than one technique whilst others lack them.

The variable methodological approach involves the type of data analysis categorized in the general approaches of articles: qualitative, quantitative and mixed (and also a category for those studies is incorporated without a methodological approach). With them we seek to define the approach to the analysis of the data in the articles, assuming that one exists and that it remains explicit in the analysis.

A variable was established to identify the academic origin (university departments) of the scholars working on the topic of OG. To do this, a variable to indicate the researchers' academic department or research institution of origin is considered, and in turn, the general areas of their departments are categorized, among the following: Law, Public Administration, Political Science, Sociology, Economics, Computer Science, Library Studies, Journalism, Communication, Information Systems, and Humanities, including a category for those without this reference. 
The variable host countries of universities and institutions denotes the geographical location where such universities or institutions are established. This classification discloses which countries produce more of this type of research. The interest of this lies in understanding the origin of the research on OG, detecting the main national perspectives which are leading this recent field of knowledge.

The variable level of government incorporates the levels of government being analyzed in OG research. Specifically, the following categories were chosen: local/municipal, regional/state, national/federal and supranational (understanding the term supranational as international organizations exercising powers in more than one nation, such as the European Union). Another category for those with more than one level was also defined, that is, that its analysis is based on more than one of the above categories. Finally, another additional category for studies that have no level of government included in the article is considered. This variable clarifies the level of government in which research is conducted, which is one of the most significant issues for the analysis.

The Analyzed Country/Areas variable, focuses on which countries are being researched in the OG articles. This shows the interest of researchers in the country object of this study. With it, it intends to understand and compare the interest, relevance and/or accessibility that exists in countries to do research on OG as well as countries in which there is empirical evidence regarding its implementation.

The main topic supposes a variable centered on the three topics of OG: Transparency, Participation and Collaboration (as mentioned in section 2) and a fourth category which indicates the significant presence of more than one topic within the analysis of the same article. This is one of the key aspects of the work, that is, to know which of the topics of OG has a higher level of interest for scholars dedicated to this field of knowledge.

Finally, the consideration of keywords is a point that requires attention in this research. While it is not the root of the selection of articles as in other research that reviews literature, there is a classification of this made in the database with all the articles, through an analysis of a "word cloud", to estimate the keywords considered most relevant in the articles. This reflects which are the most used and important concepts in the research, and so makes it possible to connect the OG with other related terms such as open data, electronic government, social media, etc.

\section{Data}

This section shows the results of the analysis on OG and dimensions and variables present in the analytical strategy, regarding the 189 items that were taken from 2011 to 2015 in order to study academic journals. The results are presented through graphs with descriptive statistics that allow 
us to reflect on the current state of affairs in the field of OG and the latest academic research in this field of knowledge. The first aspect to consider relates to the evolution of the subject in the journals analyzed. In this sense, the first idea (see Figure 1) to take into account is the growth in absolute terms in the number of published articles, which went from 24 in 2011 (34 in 2012; 33 in 2013; 45 in 2014) to 53 in 2015. In this sense, there is evidence of increasing interest in OG.

Figure 1. Sample of the articles selected

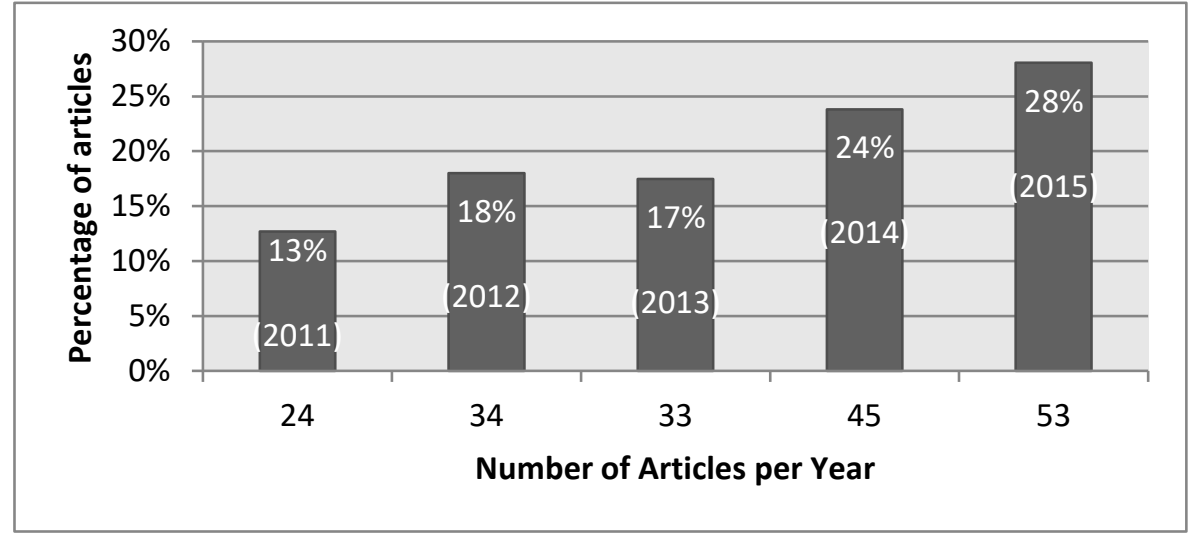

\subsection{Study design}

The first category of analysis (how is the OG analyzed?) includes the variable study design. Here, exploratory-descriptive articles widely dominated, with 138 articles, representing $73 \%$ of the total. Followed by normative articles with 23 articles representing 12\%, while items of an explanatorycorrelational and meta-analysis study design with $11 \%(21)$ and $4 \%$ (7) respectively (see Figure 2). This seems to confirm the idea of an emerging area of knowledge in which the level of formalization is still relatively limited.

Figure 2. Study design (\%)

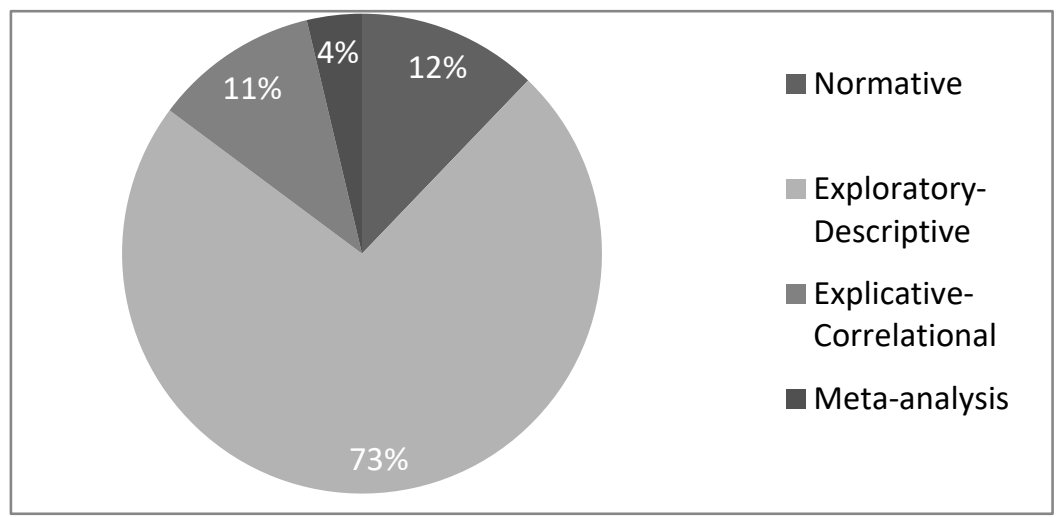




\subsection{Research techniques}

Concerning the research techniques used in the articles to collect data, some diversity has been detected, and noting the fact that there are items that include more than one of the variables analyzed. Specifically, we found that documentary analysis, which is the most predominant, is present in 108 articles. There is the use of observations in 65 articles, and similarly interviews in 57 articles. 32 articles use questionnaires. To a lesser extent, 8 articles use focus groups, and only 5 the Delphi Method; also 22 normative articles do not use a research technique (see Figure 3). It is important to note that the number $(\mathrm{N})$ of techniques gathered in the analysis was 297 since it is logical to assume that some items use more than one of the techniques categorized to do research.

Figure 3. Research techniques (\%)

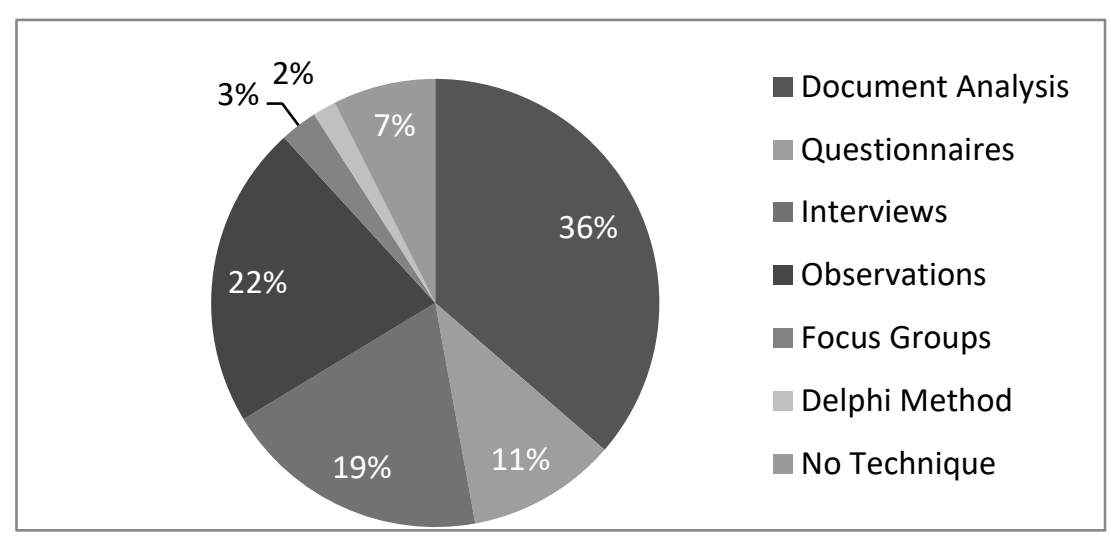

\subsection{Methodological approach}

The analysis of the two dimensions above appears to be consistent with those methodological approaches used. In the Type of Analysis or Methodological Approach it was discovered that 98 of the articles analyzed use a purely qualitative approach, followed by 26 articles with a quantitative approach, and 42 articles use a type of Mixed analysis, which represents a percentage of 52\%, $14 \%$ and $22 \%$ respectively. But from the 189 articles, 23 do not have any kind of analysis, representing $12 \%$ of the total (see Figure 4 ). 
Figure 4. Methodological approach (\%)

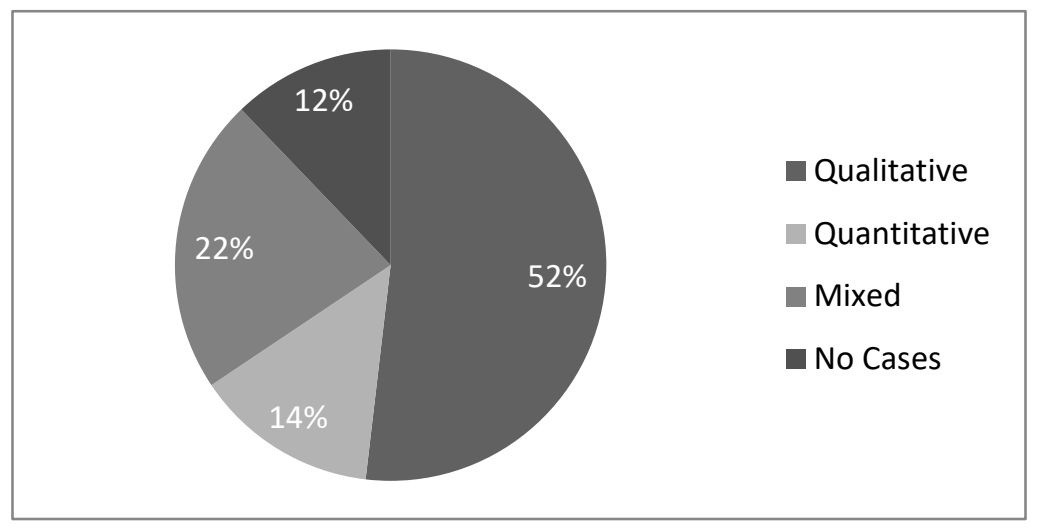

\subsection{University departments}

The second category of analysis (Where is research on OG being conducted?) includes the focus on the researcher's academic departments of origin (we based this on an N of 225 as some articles mention more than one department and others lack this information). In this case we found that the category of public administration represents $25 \%$ of the academic departments mentioned. This is followed by departments with areas of Information Systems, Computer Science, Economics, Communication and Political Science with $11 \%, 10 \%, 10 \%, 8 \%$ and 7\% respectively (see Figure 5).

Figure 5. University Departments (\%)

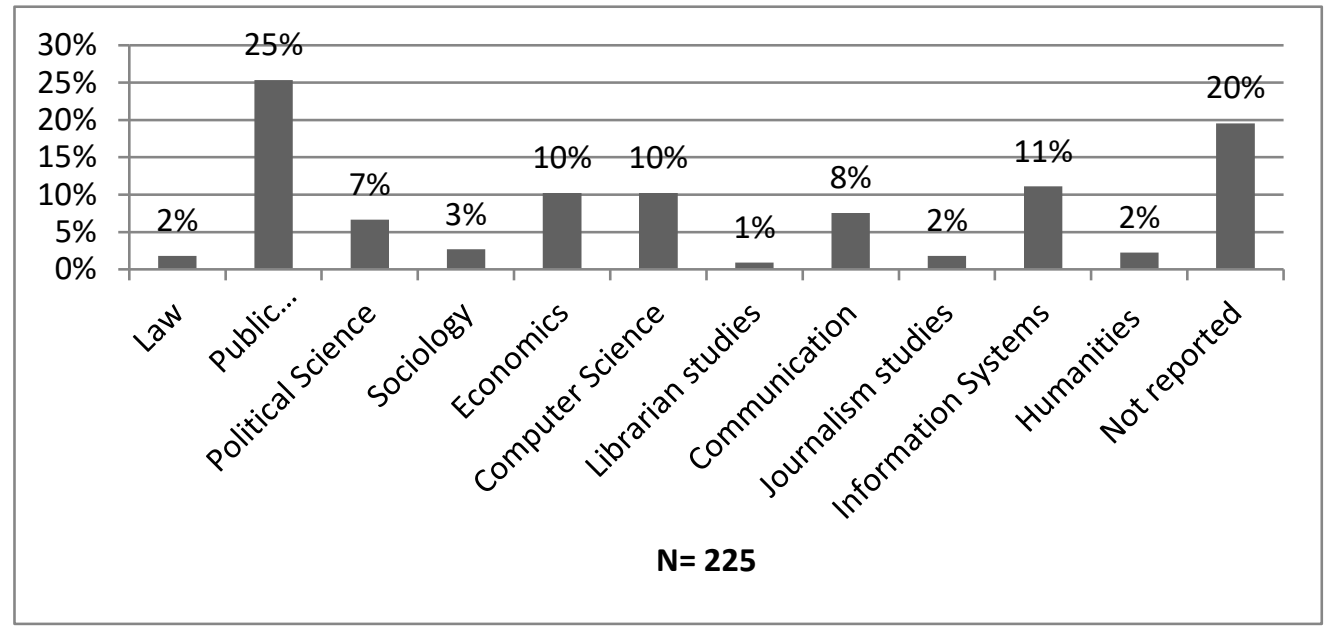

\subsection{Host countries of the universities and institutions}

Regarding the countries that are home to universities where research has been conducted, we found that the USA far outstrips other countries in the amount of research conducted, followed by the Netherlands, the UK, Germany and Mexico, as Figure 6 shows. 
Figure 6. Host countries of the universities and institutions $(N=215)$

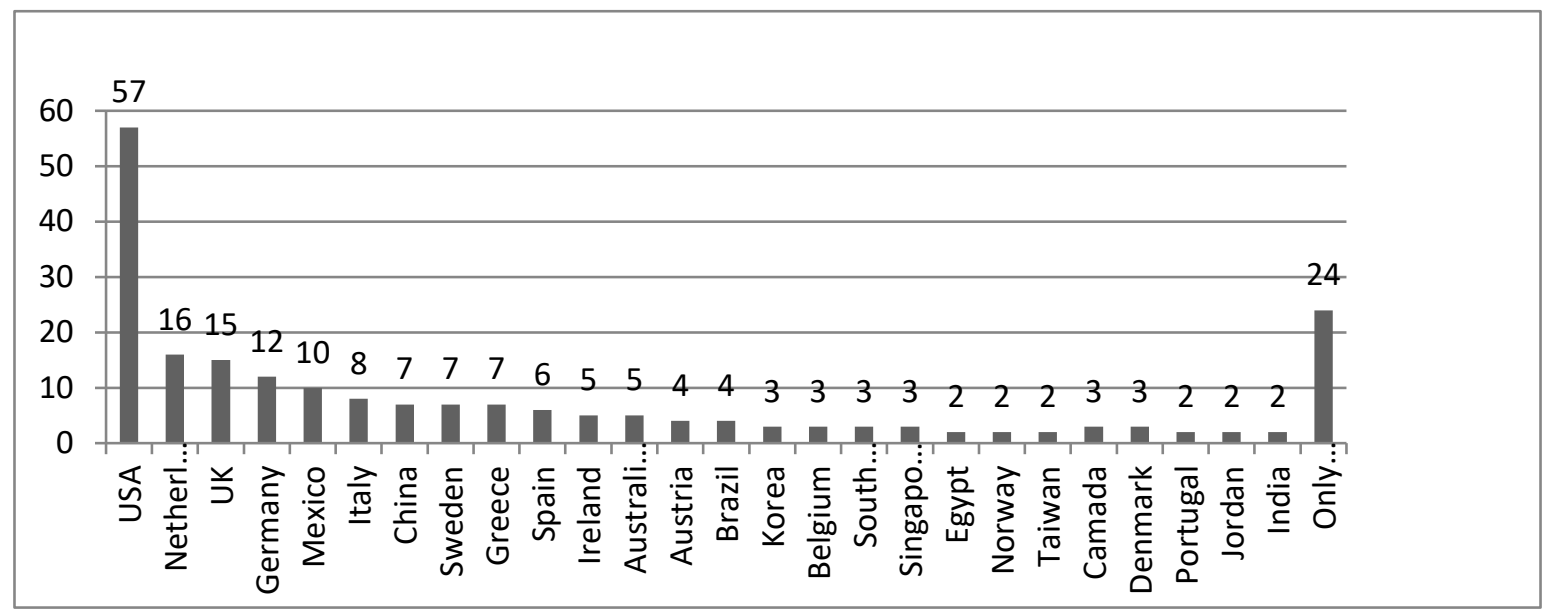

\subsection{Level of government}

Regarding the level of government where research studies are being conducted, it was found that the National/Federal level predominates with 75 articles $(40 \%)$. This is followed by the Local/Municipal level with 50 articles, representing 26\%. Subsequently, showing a considerable difference, the Regional/State level with 11 articles, is 6\%. At a Supranational level 5 articles were found equal to $3 \%$, while in the category of more than one level there are only 4 articles accounting for $2 \%$. But of the 189 articles, 44 did not define a level of study which is $23 \%$ of total of articles, especially those having normative content (see Figure 7).

Figure 7. Government level (\%)

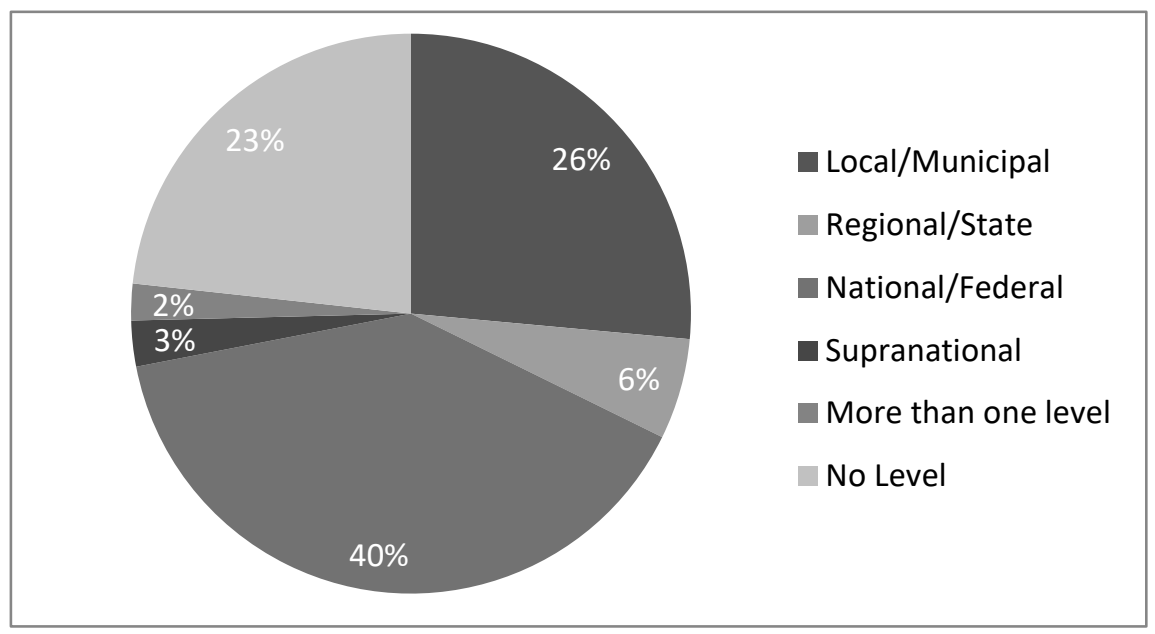




\subsection{Analyzed Country/Areas}

In the analysis of the countries that are conducting research on OG, in the selected sample, a significant difference was found between the number of articles researched in the USA and the rest. However, there is a considerable number of studies in the UK, The Netherlands, Mexico, Europe, Italy, Germany, Spain, Australia, Sweden and China, all with five or more articles. In the following cloud analysis (see Figure 8) the predominance of the countries undertaking research in connection with OG can be observed graphically, as well as the number of articles in which the countries appeared over the total number.

Figure 8. Countries/Areas (Word cloud)

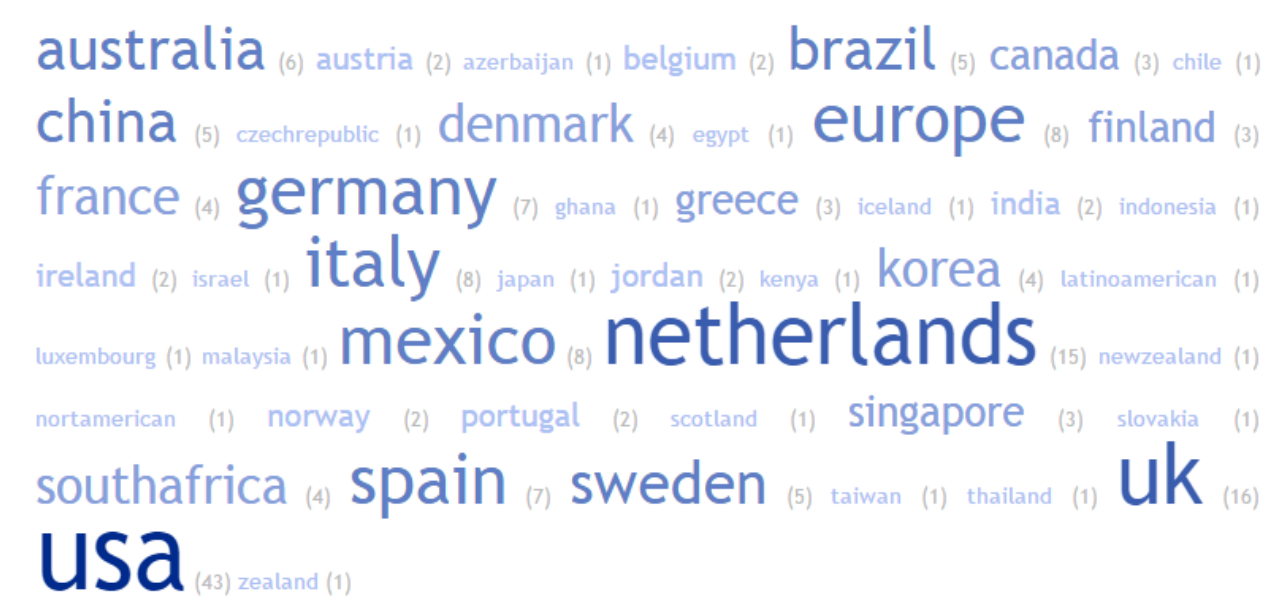

\subsection{Main topic}

Finally, the third category of analysis (What are the most analyzed topics and the most prominent concepts in the study of OG?) focuses on a terminological dimension of interest to complete this meta-analysis. Within the selected items, and according to the definitions of the three topics, (see Figure 9) the research shows that there is a strong proximity between transparency, participation and the T-P-C category, that considers more than one of the three topics explained with similarly equal relevance, with 59 articles (31\%), 58 articles (31\%) and 60 articles (32\%) respectively. Although in each year analyzed, the presence of the topics has changed, especially in recent years with a growth in the topic of participation, in sum, the homogeneity of these three indicators is a relevant finding for this analysis. However, the topic of collaboration is greatly reduced with only 12 articles representing $6 \%$ of the total, a figure that is discussed below. 
Figure 9. Main Key Topics of the articles (\%).

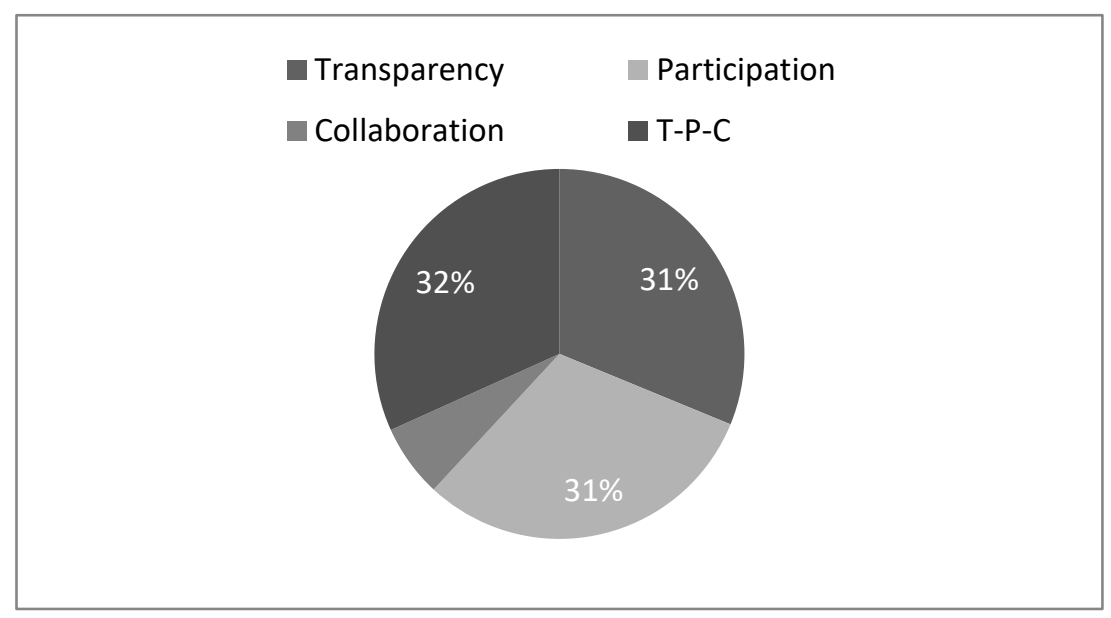

\subsection{Keywords}

Finally, the analysis of keywords represents the focus of attention of the authors at the beginning of the articles. In total, there were 1086 keywords mentioned in 189 articles. The program used for the analysis was TagCrowd. A homogenization of terms was performed, as in the example of edemocracy and e-democracy which were brought together into a single term, likewise upon not admitting numerical values, the web 2.0 concept was adjusted to webtwozero. The word analysis program automatically groups the concepts, with which a total of 619 different concepts for the analysis were obtained; to discriminate the concepts of little relevance, a filter that allows display of terms with 3 or more repetitions was chosen. The result is shown in Figure 10 with a total of 53 keywords representing the number of repetitions for each concept. 
Figure 10. Keyword analysis

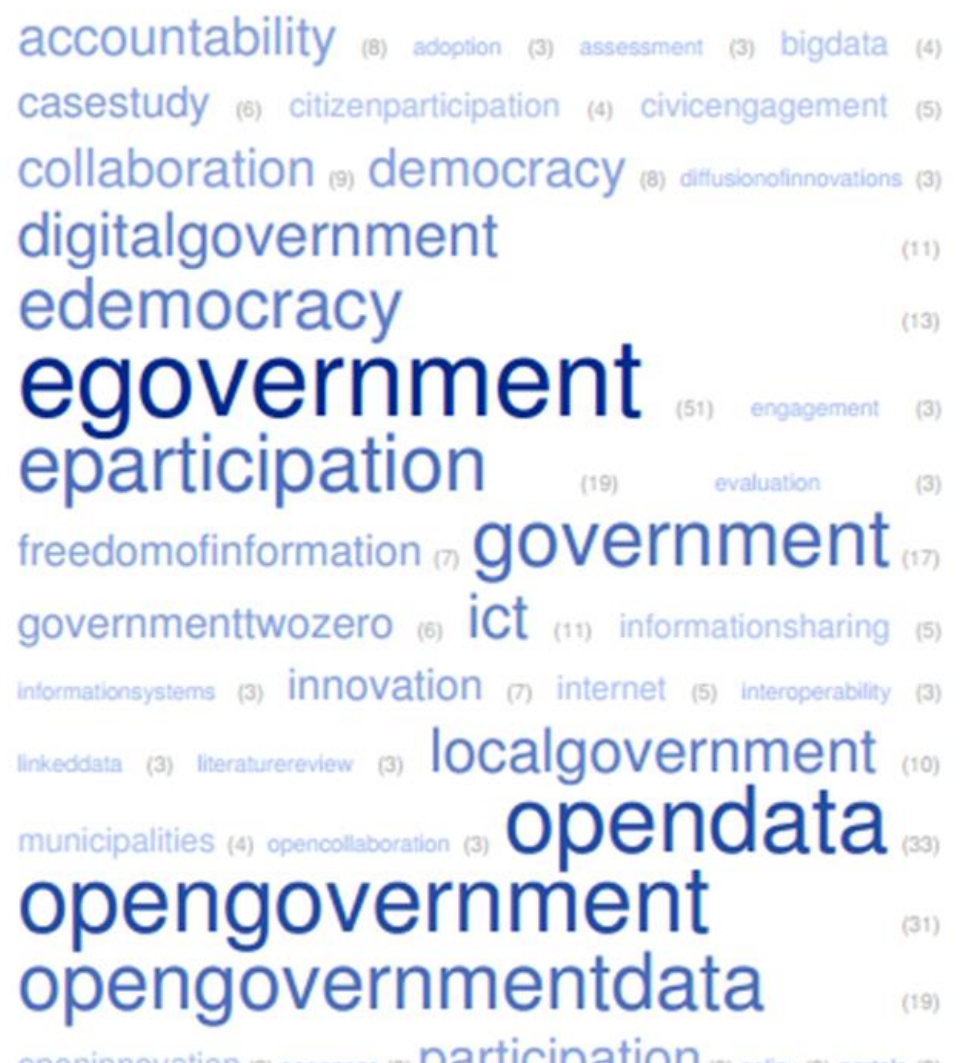

openinnovation (5) openness (3) participation (9) policy (3) porals (3)

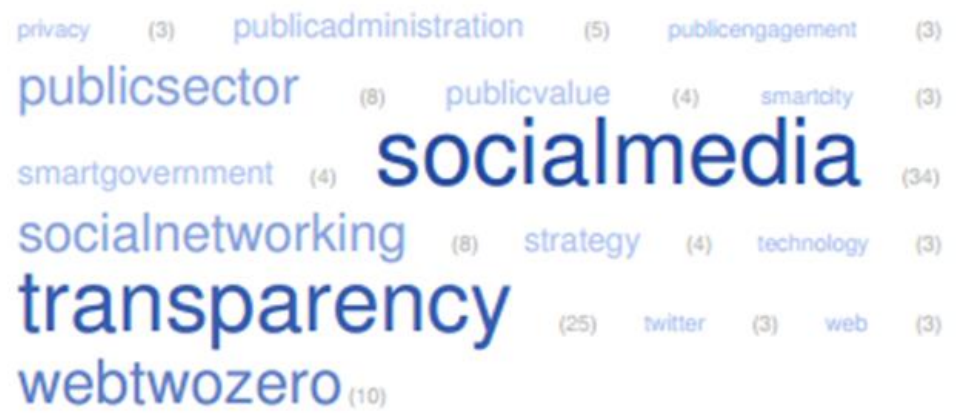

The variety of words in the keywords section of the articles demonstrate the diversity of topics of interests related to OG. From the analysis performed in TagCrowd, it is shown that the most repeated keywords in the international literature on OG are the following: Open Government, Open Data, Open Government Data, Social Media, Transparency, e-Participation, Government, and eDemocracy. This confirms that research on OG is very close to key political concepts such as democracy, transparency, and participation, as well as the new opportunities that ICT seem to offer, so that the connection between e-government, open data or digital social networks becomes increasingly evident. The latter should also not ignore the importance of other issues such as 
accountability, ensuring access to public information, or collaboration, which also established the interest of the epistemic community of OG.

\section{Discussion}

The data show that OG is being increasingly studied, although it is necessary to discuss some key aspects of the consolidation process of this research field. From the point of view of the topics (transparency, participation and collaboration) it is clear that they underlie the analysis of much of the literature on OG. Nevertheless, in the articles, we found different definitions of the terms, mainly of participation and collaboration. This leads us to question the relevance of the concepts and even the topics, as Meijer (2012) makes reference to collaboration, a concept seen as generated from the relationship between participation and transparency. The appendix shows all the articles analyzed, along with the topics of reference and the key concepts most used in each of the three cases.

Transparency as a topic of OG is strongly associated with the right of access to information and accountability. It is just that transparency in the open government involves a digital transparency, based on open data (Bannister and Connolly, 2014; Bates, 2014; Janssen and van den Hoven, 2015; Kimball, 2011; Thompson et al.2015; Zuiderwijk et al. 2015) and the exercise of a fundamental right, such as access to public information. Thus, the first stage of the OG is transparency but it is an insufficient condition. It requires collaboration via citizen participation. The latter, located in the area of collaboration to improve the quality of public policies and to establish new ways of governing, but also to recreate conditions for development. Achieving an OG involves public ethics and commitment to transparency and participation to co-create and collaborate. It is also considered that transparency is a signal of legitimate governments (Sandoval, 2011) and has even become a social demand today. This is the idea of government legitimacy linked to transparency - it reinforces this legitimacy, and confidence of a society in government (Hood, 2011; Jaeger and Bertot, 2010).

Transparency and participation are interdependent concepts to design open governments. According to Harrison and Sayogo (2014) transparency and participation have features that are complementary to an effective governance model. Participation represents a great value in civil society, and it is related to the involvement in political processes and, as a consequence, with consultation and deliberation with citizens, and participation in decision-making and public

policy development. After the massive increase in use of ICT and in particular the Internet, participation found a new way to converge and link citizens with their governments, which gave rise to the concept of e-participation. This concept has led to studies closely linked to social networks and social media (Aström et al 2012; Bonsón and Ratkai, 2015; Gulati et al 2014. Jho and 
Song, 2015; Medaglia , 2012; Sæbø et al 2008; Susha and Grönlund, 2014; Vicente and Novo,2014; Zheng et al., 2014).

The data show that transparency and participation are two elements that are very internalized and linked to the practical concept of OG. This leads us to assert that these two elements are the ones that set the foundation for a new management model, and that from these elements derive concepts and elements of great importance that are gaining ground within the OG consolidation, such as: open data, accountability and social media. To some extent, this aspect suggests a highly applied or practical direction undertaken by the research of OG.

Within participation there is a strong tendency toward the study of electronic participation or e-participation, because the OG relies on the use of ICT. Mainly there has been a revival of citizen participation as a result of the general use of the Internet within society (Castells, 1997), as well as the new social technological platforms available to deepen the relationship with citizens (Mergel, 2014. Criado et al, 2013; Noveck, 2015). In this sense, tools such as apps, digital social networks, geolocation tools, open data portals, etc., offer new opportunities to generate smart governance of political communities.

Collaboration for Gascó (2015) has to do with interoperability, co-production and social innovation and, therefore, the design, provision and evaluation of public services that generate public value. Lopez (2014) fully associated collaboration with the co-design of public policies and collective action. On the other hand, Lee and Kwak (2012) establish collaboration as a higher level of maturation of the OG, above transparency and participation, involving increased interaction between government agencies and civil society. Thus, the OG is perceived as being based on a maturity model related to the three topics of transparency, participation and collaboration.

Digital spaces have also been constructed in collaboration with citizens? as concrete examples of their development. Mainly, platforms such as Wikipedia show the potential of co-production. For its part, the government has also made platforms to intercommunicate between areas and sectors (Scholl et al 2012; Linders, 2012; Fedorowicz et al 2014. Panagiotopoulos 2014 et al.). Thus, interoperability, co-production, horizontality within social media and online social networks have collaborative features, but are not always applied in this way by the governments that use them.

The concept of collaboration is perhaps the least formalized of the three topics and the one that generates more debate in the international literature. Collaboration raises a point of discussion about whether it is of comparable value to the other two components of the OG (Ganapati and Reddick, 2012; Lathrop and Ruma, 2010; McDermott, 2010). In fact, Valenzuela (2013) states that the limited collaboration exclusively between governmental actors is insufficient, given that the state is currently becoming less autonomous, and is aimed towards new associative forms of collaboration between government and society. 
One aspect that comes to light in the analysis is the transversality of the topics. This is extremely interesting, because it is positioned slightly above transparency and participation as an independent element and shows that almost a third of the articles analyzed assume a comprehensive analysis of the topic elements of OG. This aspect can be interpreted as a starting point on the road towards the consolidation of a holistic theory of study in relation to the OG.

Today, we can note that the OG phenomenon has mutated since 2009. The ideas of access to public information, accountability and practices for democratization have already been reflected in government policies. Some promoters of open government are convinced that the term only means modernization of public administration. Furthermore, the new paradigm of smart governance under the umbrella concept of OG is highly debated. According to the author's opinion, there is no complete unanimity regarding the term OG, nor on the relevance of new technologies, nor on how to implement it in different administrative contexts. However, a point in which most authors have reached agreement is the existence of the three topics of OG: Transparency, Participation and Collaboration, as well as its profound impact on the activity of governing societies.

\section{Conclusions}

The data presented in this article are able to descriptively respond to the research questions that were initially raised and help to explain the path traveled so far and to approach future scenarios. Undoubtedly, the path traveled by OG research is at an early stage. This article establishes a precedent in the research on OG to help identify areas of opportunity, as well as some of the shortcomings and limitations of this new epistemic community.

The first research question 1 (RQ1) delves into How is the OG being analyzed? To start, there has been a sustained growth between 2011 and 2015 in the publication of articles in the international journals that have produced the most on the subject. The exploratory-descriptive design of the articles strongly predominates among the different study designs used in the research about OG. Followed by the normative and explanatory-correlational study design and the minority by meta-analysis. This explains the increase in data and the need for empirical evidence about this research topic.

The documentary analysis is presented as the main research technique used to collect data, followed by interviews and observations. There are also the questionnaires, and considered underused, are the focus groups and the Delphi method. This suggests a challenge oriented to measuring the impact of OG policies. Within the general methodological approaches (qualitative and quantitative) it was found that a majority used a qualitative approach (52\%), followed by a mixed methodology (22\%) and then the quantitative approach (14\%). Nonetheless, one may suggest that the quantitative approach in future studies will increase due to the increase of studies 
and the evolution of the field. In summary, the data of this dimension on how the OG is being studied can be interpret as: there is a tendency to reveal more quantitative data, which provides evidence of some case studies which become important in the creation of public policies and structural changes in public management.

The second research question 2 (RQ2) refers to where the OG is being analyzed. Academic and research institutions where a higher production of these issues were presented are the following: Public Administration (representing 25\%), followed by departments with areas of Information Systems (11\%), Computer Science (10\%), Economics (10\%), Communication (8\%), and Political Science $(7 \%)$. This indicates an important consolidation of topics on the use of technology in government and the involvement of researchers from areas of knowledge different from the areas of the Social Sciences.

In addition, available data also show issues of certain importance. Regarding the level of government in which the research studies considered in the analysis are conducted, we found that the national level is the most studied, followed by the local, and subsequently, with a considerable difference, the regional. At the supranational level and category of more than one level, very little interest was observed. Nevertheless, out of the total sample, nearly a quarter does not define a level of study. With regard to the countries that are being researched in any level of government, it was found that there is a certain logical match with the host countries of institutions and universities researching it. Among the countries USA strongly dominated, followed by the UK, the Netherlands, Mexico, Europe (supranational whole), Italy, Germany, Spain, Australia, Sweden and China.

Thirdly, the research question (RQ3) is posed. What are the most analyzed topics and the most prominent concepts in the study of OG? Within this framework of literature one can appreciate in the classification of the three topics, transparency and participation represent two topics with a strong presence which are consolidated in OG research, while the topic of cooperation was found to be considerably behind. Nonetheless, the cross-sectional study T-P-C of the topics of the OG has a significant relevance with $32 \%$ of the articles analyzed. This indicates that there is a broad understanding of all the topics in the OG although it is appreciated that many studies conceive transparency or participation as central axes of the OG.

International literature confirms that the $O G$ is presented as an idea of reinventing the government system, of adding democratic values, open data and social inclusion. In other words, the benefits that researchers give the OG are vast and scattered, representing a widespread aspiration to overcome the conventional dynamics of the new public management and public governance limitations. The diversity of the phenomenon and plurality of the topics that are addressed within the concept of OG reveal holistically that it is a paradigm with the purpose of maintaining a permanent dialogue with citizens, where the government system revolves around 
active citizenship to generate synergies with government institutions in a collaborative and transparent manner.

This research presents some methodological limitations. On the one hand, three scientific journals that publish their content in English are analyzed, which excludes publications in other languages that may include valuable research. Within the dissemination of research on OG there are also international conferences and congresses, yet they are not considered in this research study. However, this limitation does not reduce the interest of the analysis since it is not intended to be completely comprehensive, but to consider the major advances in the academic community that is working on OG internationally. Future studies could extend the literature review, include other types of publications or measure the social impact of this phenomenon.

Equally, the "content analysis" of the articles as a technique for inclusion in the sample can also be criticized, by not rigidly limiting the parameters and selection criteria. Nonetheless, this technique allows investigation from the rational intentionality of the object of research, and it is of great qualitative value, unlike literature review methods that analyze a more limited selection of articles based on keywords or summaries. In these cases, a qualitative work of great value to achieve a meta-evaluation such as the one provided in this article is not developed.

Finally, research in OG has a long way to go, as has been highlighted in this article. This research aims to provide an open door to continue studying the behavior of the OG because, every day, the community of researchers who work under this theoretical and conceptual label becomes broader. At the same time, the diversity of backgrounds of researchers and the lack of terminological concretion, possibly pose a difficulty to consolidate an epistemic community associated with OG. Therefore, it is essential to increase international dialogue among scholars working in this field of study and achieve comparative research internationally and with more sophisticated and plural research methods. All of this is essential for the OG to mature as a field of academic knowledge and the fulfilment of the hopes of millions of people regarding the transformation of political institutions worldwide.

\section{References}

Abu-Shanab, E. A. (2015). Reengineering the open government concept: An empirical support for a proposed model. Government Information Quarterly, 32(4), 453-463.

Aström, J., Karlsson, M., Linde, J., \& Pirannejad, A. (2012). Understanding the rise of e-participation in nondemocracies: Domestic and international factors. Government Information Quarterly, 29(2), 142-150.

Attard, J., Orlandi, F., Scerri, S., \& Auer, S. (2015). A systematic review of open government data initiatives. Government Information Quarterly, 32(4), 399-418.

Bannister, F., \& Connolly, R. (2011). Trust and transformational government: A proposed framework for research. Government Information Quarterly, 28(2), 137-147. 
Bannister, F., \& Connolly, R. (2014). ICT, public values and transformative government: A framework and programme for research. Government Information Quarterly, 31(1), 119-128.

Bates, J. (2014). The strategic importance of information policy for the contemporary neoliberal state: The case of open government data in the United Kingdom. Government Information Quarterly, 31(3), 388395.

Bonsón, E., Royo, S., \& Ratkai, M. (2015). Citizens' engagement on local governments' Facebook sites. An empirical analysis: The impact of different media and content types in Western Europe. Government Information Quarterly, 32(1), 52-62.

Castells, Manuel (1996). The Information Age. The Rise of the Network Society, Vol. I, Blackwell: Oxford.

Chapman, R \& Hunt, M. (Eds.) (1987). Open Government. A study of the prospects of open government within the limitations of the British political system, Routledge, London.

Clarke, A., \& Francoli, M. (2014). What's in a name? A comparison of 'open government' definitions across seven open government partnership members. EJournal of eDemocracy and Open Government, 6(1), 248-266.

Criado, J. Ignacio. (ed.) (2016). New Trends in Public Management. Open Innovation, Smart Governance andSocial Technologies in Collaborative Public Administrations. (in Spanish) Nuevas Tendencias en la Gestión Pública.Innovación Abierta, Gobernanza Inteligente y Tecnologías Sociales en unasAdministraciones Públicas Colaborativas. Madrid: Instituto Nacional deAdministración Pública.

Criado, J. I., \& Ruvalcaba-Gomez, E. A. (2018). Perceptions of City Managers About Open Government Policies: Concepts, Development, and Implementation in the Local Level of Government in Spain. International Journal of Electronic Government Research (IJEGR), 14(1), 1-22.

Criado, J. I.,Sandoval-Almazán, R., \& Gil-García, J. R. (2013) Government innovation through social media. GovernmentInformation Quartely, 30(4), 319-326.

Dekker, R., \& Bekkers, V. (2015). The contingency of governments' responsiveness to the virtual public sphere: A systematic literature review and meta-synthesis. Government Information Quarterly, 32(4), 496-505.

Denyer, D. \& Tranfield, D. (2009). Producing a systematic review, in Buchanan, D. and Brymand, A. (Eds). The Sage Handbook of Organizational Research Methods, Sage Publications, London, pp. 671-689.

Estevez, E., \& Janowski, T. (2013). Electronic governance for sustainable development - conceptual framework and state of research. Government Information Quarterly, 30, Supplement 1(0), S94-S109.

Fedorowicz, J., Sawyer, S., Williams, C. B., Markus, M. L., Dias, M., Tyworth, Schrier, R. (2014). Design observations for interagency collaboration. Government Information Quarterly, 31(2), 302-316.

Ganapati, S., \& Reddick, C. G. (2012). Open e-government in US state governments: Survey evidence from chief information officers. Government Information Quarterly, 29(2), 115-122.

Gascó, M. (2015). Guía de buenas prácticas en gobierno abierto (Guide of good practices on open government). Bogota (Colombia): Universidad Externado de Colombia. 
Gascó, M. (2014). Open government. Opportunities and challenges for public governance. New York: Springer.

Gil-Garcia, J. R., Dawes, S. S., \& Pardo, T. A. (2017). Digital government and public management research: finding the crossroads. Public Management Review, 20 (5), 633-646.

Gonzalez-Zapata, F., \& Heeks, R. (2015). The multiple meanings of open government data: Understanding different stakeholders and their perspectives. Government Information Quarterly, 32(4), 441-452.

Grimmelikhuijsen, S. G. (2012). Transparency and trust. An experimental study of online disclosure and trust in government (Doctoral thesis). Utrecht University, Netherlands.

Gulati, G. J., Williams, C. B., \& Yates, D. J. (2014). Predictors of on-line services and e-participation: A crossnational comparison. Government Information Quarterly, 31(4), 526-533.

Harrison, T. M., \& Sayogo, D. S. (2014). Transparency, participation, and accountability practices in open government: A comparative study. Government Information Quarterly, 31(4), 513-525.

Hartley, J. and Kostoff, R. N. (2003). How useful are "Key Words" in Scientific Journals? Journal of Information Science, 29 (5), pp. 433-438

Hood, Christopher (2011). From FOI world to wikileaks world: A new chapter in the transparency story? Governance, 24(4), 635-638.

Jaeger, Paul T. \& Bertot, John Carlo (2010). Transparency and technological change: Ensuring equal and sustained public access to government information. Government Information Quarterly, 27(4), 371376.

Janowski, T. (2015). Digital government evolution: From transformation to contextualization. Government Information Quarterly, 32(3), 221-236.

Janssen, M., \& van den Hoven, J. (2015). Big and open linked data (BOLD) in government: A challenge to transparency and privacy? Government Information Quarterly, 32(4), 363-368.

Jho, W., \& Song, K. J. (2015). Institutional and technological determinants of civil e-participation: Solo or duet? Government Information Quarterly, 32(4), 488-495.

Kimball, M. B. (2011). Mandated state-level open government training programs. Government Information Quarterly, 28(4), 474-483.

Lathrop, D., \& Ruma, L. (2010). Open government: Collaboration, transparency, and participation in practice "O'Reilly Media, Inc.".

Lee, G., \& Kwak, Y. H. (2012). An open government maturity model for social media-based public engagement. Government Information Quarterly, 29(4), 492-503.

Linders, D. (2012). From e-government to we-government: Defining a typology for citizen coproduction in the age of social media. Government Information Quarterly, 29(4), 446-454.

López, J.F. (2014) ¿Pueden los estados seguir gobernando nuevas ciudadanías bajo viejos paradigmas?: Los desafíos políticos del Gobierno Abierto en América Latina y el Caribe. Banco Interamericano de Desarrollo (BID). 
Luna-Reyes, L. F., \& Gil-Garcia, J. R. (2014). Digital government transformation and internet portals: The co-evolution of technology, organizations, and institutions. Government Information Quarterly, 31(4), 545-555.

McDermott, P. (2010). Building open government. Government Information Quarterly, 27(4), 401-413.

Medaglia, R. (2012). eParticipation research: Moving characterization forward (2006-2011). Government Information Quarterly, 29(3), 346-360.

Meijer, A. J., Curtin, D., \& Hillebrandt, M. (2012). Open government: Connecting vision and voice. International Review of Administrative Sciences, 78(1), 10-29.

Meijer, A., \& Bekkers, V. (2015). A metatheory of e-government: Creating some order in a fragmented research field. Government Information Quarterly, 32(3), 237-245.

Michener, G., \& Bersch, K. (2013). Identifying transparency. Information Polity: The International Journal of Government \& Democracy in the Information Age, 18(3), 233-242.

Noveck, B. S. (2015). Smart citizens, smarter state: The technologies of expertise and the future of governing. Harvard University Press.

Noveck, B. S. (2017). Rights-Based and Tech-Driven: Open Data, Freedom of Information, and the Future of Government Transparency. Yale Hum. Rts. \& Dev. LJ, 19, 1.

Obama, B. (2009). Transparency and open government. Memorandum for the heads of executive departments and agencies. Federal Register, 74(15), 4685-4686.

OECD (2011), Together for Better Public Services: Partnering with Citizens and Civil Society, OECD Public Governance Reviews, OECD Publishing.

Panagiotopoulos, P., Bigdeli, A. Z., \& Sams, S. (2014). Citizen-government collaboration on social media: The case of twitter in the 2011 riots in england. Government Information Quarterly, 31(3), 349-357.

Parks, W. (1957). The open government principle: applying the right to know under the Constitution. The George Washington Law Review, 26 (1)

Peschard, J. (2013). Del gobierno abierto a la transparencia proactiva: la experiencia del IFAI en 2011. Hofmann; Ramírez-Alujas \& Bojórquez, La promesa del gobierno abierto. México, ITAIP.

Piotrowski, S. J. (2017). The “Open Government Reform” Movement: The Case of the Open Government Partnership and US Transparency Policies. The American Review of Public Administration, 47(2), 155171.

Rana, N. P., \& Dwivedi, Y. K. (2015). Citizen's adoption of an e-government system: Validating extended social cognitive theory (SCT). Government Information Quarterly, 32(2), 172-181.

Ruvalcaba-Gomez, E. A., Criado, J. I., \& Gil-Garcia, J. R. (2018). Discussing open government as a concept: a comparison between the perceptions of public managers and current academic debate. In Proceedings of the 19th Annual International Conference on Digital Government Research: Governance in the Data Age (p. 71). ACM. 
Sæbø, Ø., Rose, J., \& Skiftenes Flak, L. (2008). The shape of eParticipation: Characterizing an emerging research area. Government Information Quarterly, 25(3), 400-428

Sandóval-Almazán, Rodrigo (2011), "The two door perspective: An assessment framework for open government", eJournal of eDemocracy and Open Government, 3(2): 166-181.

Schnell, S. (2017) Cheap talk or incredible commitment? (Mis) calculating transparency and anti-corruption. Governance, 1-16.

Scholl, H. (2009). Profiling the EG research community and its core. In M. A. Wimmer, H. J. Scholl, M. Janssen, \& R. Traunmüller (Eds.), Proceedings of 8th international conference on electronic government, EGOV 2009 (pp. 1-12). Berlin/Heidelberg: Springer LNCS 5693.

Scholl, H. J., Kubicek, H., Cimander, R., \& Klischewski, R. (2012). Process integration, information sharing, and system interoperation in government: A comparative case analysis. Government Information Quarterly, 29(3), 313-323.

Sivarajah, U., Irani, Z., \& Weerakkody, V. (2015). Evaluating the use and impact of Web 2.0 technologies in local government. Government Information Quarterly, 32(4), 473-487.

Susha, I., \& Grönlund, Å. (2012). eParticipation research: Systematizing the field. Government Information Quarterly, 29(3), 373-382.

Thompson, N., Ravindran, R., \& Nicosia, S. (2015). Government data does not mean data governance: Lessons learned from a public sector application audit. Government Information Quarterly, 32(3), 316322.

Tranfield, D., Denyer, D. \& Smart, P. (2003). Towards a Methodology for Developing Evidence-Informed Management Knowledge by Means of Systematic Review. British Journal of Management, 14, pp. 207222.

Valenzuela, R. (2013). Delimitar Gobierno Abierto para ampliar la Colaboración con una Sociedad más Abierta. Estado, Gobierno y Gestión Pública, 21, pp. 127-158.

Vicente, M. R., \& Novo, A. (2014). An empirical analysis of e-participation. The role of social networks and e-government over citizens' online engagement. Government Information Quarterly, 31(3), 379-387.

Webster, J., \& Watson, R. T. (2002). Analyzing the past to prepare for the future: Writing a literature review. MIS Quarterly, 26(2), XIII-XXIII.

Wijnhoven, F., Ehrenhard, M., \& Kuhn, J. (2015). Open government objectives and participation motivations. Government Information Quarterly, 32(1), 30-42.

Wolfswinkel, J. F., Furtmueller, E. \& Wilderon, C. (2013). Using grounded theory as a method for rigorously reviewing literature. European Journal of Information Systems, 22, pp. 45-55.

Zheng, Y., Schachter, H. L., \& Holzer, M. (2014). The impact of government form on e-participation: A study of New Jersey municipalities. Government Information Quarterly, 31(4), 653-659. 
Zuiderwijk, A., Janssen, M., \& Dwivedi, Y. K. (2015). Acceptance and use predictors of open data technologies: Drawing upon the unified theory of acceptance and use of technology. Government Information Quarterly, 32(4), 429-440.

\begin{abstract}
About the Authors
J. Ignacio Criado is an associate professor at Department of Political Science and International Relations, Universidad Autónoma de Madrid. His research about different dimensions of democracy, government and public administration, and public management and their interplay with Internet and information andcommunication technology has been published in Government Information Quarterly, Social Science Computer Review, Information Polity, International Journal of Electronic Government Research, International Journal of Electronic Governance, Internacional Journal of Public Sector Management, or First Monday, among others.
\end{abstract}

Edgar Alejandro Ruvalcaba Gómez holds a PhD in Law, Government and Public Policy from Autonomous University of Madrid (UAM), Spain, a Master Degree in Public Policy, and another Master Degree in Public Management in Virtual Environments, both by University of Guadalajara (UDG), México. He holds a Law Bachelor's Degree by UDG. Edgar conducts research related to Open Government, Transparency, Citizen Participation, Open Data, Digital Government and Public Innovation. He has been a Visiting Scholar at Trinity College in Dublin, Ireland, and at the Center for Technology in Government (CTG), University at Albany, New York, USA. He currently works as a Subnational Researcher for the Independent Reporting Mechanism (IRM) of the Open Government Partnership.

Rafael Valenzuela-Mendoza is Full Professor at Social Science and AdministrationInstitute by Autonomous University of Juarez City (Mexico) since 2015. He holdsPhD in Public Policy from the Graduate School of Public Administration andPublic Policy (EGAP)of the Monterrey's High Studies Technology Institute(ITESM). Currently researching a project with funding by the National Councilof Sciences and Technology (CONACYT), Basic Science, entitled Theorganizational dimension of open government, CONACYT agreement number257040. 


\section{Appendix}

Overview of Open Government research articles

\begin{tabular}{|c|c|c|}
\hline Author & Topic & Keywords \\
\hline $\begin{array}{l}\text { Armstrong (2011), Bannister and Connolly (2011), } \\
\text { Bannister and Connolly (2014), Barry and Bannister } \\
\text { (2014), Bates (2014), Batista (2013), Bekkers et al. } \\
\text { (2013), Bertot et al. (2014), Bonsón et al. (2012), Chen } \\
\text { (2012), Cherry and McMenemy (2013), Conradie and } \\
\text { Choenni (2014), Cuadrado-Ballesteros (2014), de } \\
\text { Mendonça et al. (2015), Graves and Hendler (2014), } \\
\text { Grimmelikhuijsen (2011), Grimmelikhuijsen (2012), } \\
\text { Gutiérrez et al. (2014), Hartog et al. (2014), Heimstädt } \\
\text { et al. (2014), Iemma et al. (2014), Janssen (2011), } \\
\text { Janssen and Van den Hoven (2015), Jin and Moon } \\
\text { (2015), Khayyat and Bannister (2015), Kimball (2011), } \\
\text { Kučera and Chlapek (2014), Lamdan (2013), Lemieux } \\
\text { et al, (2015), Linders (2013), Lio et al. (2011), Lourenço } \\
\text { (2013), Lourenço (2015), Meijer et al. (2014), Meng } \\
\text { (2014), Michener and Bersch (2013), Nam (2012), } \\
\text { Owen et al. (2013), Papaloi and Gouscos (2013), Peled } \\
\text { (2013), Peled (2015), Petrou et al. (2014), Puron-Cid } \\
\text { (2014), Rao and Kirti (2012), Sandoval-Almazán } \\
\text { (2011), Sayogo and Pardo (2013), Sayogo et al. (2014), } \\
\text { Shepherd et al. (2011), Sloot (2011), Teresa Scassa and } \\
\text { Singh (2015), Thompson et al. (2015), Veljković et al. } \\
\text { (2014), Wenjing (2011), Whitmore (2014), Yang et al. } \\
\text { (2014), Zuiderwijk and Janssen (2014), Zuiderwijk } \\
\text { and Janssen (2015), Zuiderwijk et al. (2012), } \\
\text { Zuiderwijk et al. (2014). }\end{array}$ & Transparency & $\begin{array}{l}\text { - } \text { e-Government } \\
\text { - Open data } \\
\text { - Transparency } \\
\text { - Open Gov } \\
\text { - e-Democracy } \\
\text { - e-Participation } \\
\text { - Open } \\
\text { - } \text { Government data } \\
\text { - Freedom } 2.0 \\
\text { Information }\end{array}$ \\
\hline
\end{tabular}




\begin{tabular}{|c|c|c|}
\hline $\begin{array}{l}\text { Abdelsalam et al. (2013), Alexopoulos et al (2014), } \\
\text { Andersen et al. (2012), Aström et al. (2012), Bonsón et } \\
\text { al. (2015), Breindl (2012), Bridges et al. (2012), Bruns } \\
\text { and Swift (2011), Buente 2015, Cegarra-Navarro et al. } \\
\text { (2014), De Reuver et al. (2013), Dekker and Bekkers } \\
\text { (2015), Douglas et al. (2015), Federici et al. (2015), } \\
\text { Gulati et al. (2014), Gustafsso and Wihlborg (2013), } \\
\text { Holgersson and Karlsson (2014), Ingrams (2015), Jho } \\
\text { and Song (2015), Kavanaugh et al. (2012), Kavanaugh } \\
\text { et al. (2014), Leong (2015), Lev-On and Steinfeld } \\
\text { (2015), Medaglia (2012), Mergel (2013), Molinari } \\
\text { (2012), Molinari and Porquier (2011), Mossberger et } \\
\text { al. (2013), Muneo and Tkach-Kawasaki (2015), } \\
\text { Oliveira and Welch (2013), Papaloi and Gouscos } \\
\text { (2011), Picazo-Vela et al. (2012), Reddick and Norris } \\
\text { (2013), Robertson et al. (2013), Rodríguez and Pedro } \\
\text { (2015), Scherer and Wimmer (2012), Serup (2012), } \\
\text { Sieber and Johnson (2015), Smith (2015), Soon (2013), } \\
\text { Strauß et al. (2015), Susha and Grönlund (2012), Susha } \\
\text { and Grönlund (2014), Svensson (2011), Sæbø et al. } \\
\text { (2011), Thapa et al. (2015), Twinomurinzi et al. (2012), } \\
\text { Venkatesh et al. (2014), Vicente and Novo (2014), } \\
\text { Wandhoefer et al. (2011), Welch and Feeney (2014), Yi } \\
\text { et al. (2013), Young (2013), Zavattaro et al. (2015), } \\
\text { Zeng (2015), Zheng and Zheng (2014), Zheng et al. } \\
\text { (2014). }\end{array}$ & Participation & $\begin{array}{ll}\text { - } & \text { e-Participation } \\
\text { - } & \text { e-Government } \\
\text { - } & \text { Social media } \\
\text { - } & \text { e-Democracy } \\
\text { - } & \text { Social } \\
& \text { networking } \\
\text { - } & \text { Web } 2.0\end{array}$ \\
\hline $\begin{array}{l}\text { Chatfield et al. (2013), Dawes et al. (2012), Fedorowicz } \\
\text { et al. (2014), Panagiotopoulos et al. (2014), Ferroa et } \\
\text { al. (2013), Linders (2012), Meijer and Thaens (2013), } \\
\text { Mergel (2015), Ojo et al. (2011), Scholl et al. (2012), } \\
\text { Spaiser (2012), Thomas et al. (2015). }\end{array}$ & Collaboration & $\begin{array}{l}\text { - } \text { Social media } \\
\text { - Network } \\
\text { - Governance } \\
\text { - Information } \\
\text { - } \text { sharing } \\
\text { - } \text { Collaboration } \\
\text { - } \text { e-Collaboration } \\
\text { - Interoperation }\end{array}$ \\
\hline
\end{tabular}




\begin{tabular}{|c|c|c|}
\hline $\begin{array}{l}\text { Abu-Shanab (2015), Attard (2015), Bartenberge and } \\
\text { Grubmüller (2014), Bedini et al. (2014), Bertot et al. } \\
\text { (2012), Bug and Röllgen (2011), Chun and Cho (2012), } \\
\text { Clarke and Francoli (2014), Cordella and Tempini } \\
\text { (2015), Criado et al. (2013), Danneels and Viaene } \\
\text { (2015), Deckert et al. (2011), Estevez and Janowski } \\
\text { (2013), Fechner and Kray (2014), Francoli (2011), } \\
\text { Ganapati and Reddick (2012), Geiger and Jörn (2012), } \\
\text { Gil-Garcia (2012), Gonzalez-Zapata and Heeks (2015), } \\
\text { Graves and Hendler (2011), Harrison and Sayogo } \\
\text { (2014), Harrison et al. (2012), Janowski (2015), Janssen } \\
\text { and Estevez (2013), Jung and Park (2015), Kassen } \\
\text { (2013), Lee and Kwak (2012), Lips (2012), Luna et al. } \\
\text { (2013), Luna-Reyes and Gil-Garcia (2014), Maier- } \\
\text { Rabler and Huber (2011), Meijer (2015), Meijer and } \\
\text { Bekkers (2015), Mergel 2012 , Mergel (2013), } \\
\text { Ohemeng and Ofosu-Adarkwa (2015), Ostling (2012), } \\
\text { Paulin (2014), Rana and Dwivedi (2015), Sandoval } \\
\text { and Gil-Garcia (2012), Sivarajah et al. (2015), Smith } \\
\text { and Health (2014), Snead (2013), Stamati et al. (2015), } \\
\text { Taylor (2012), Toshkov (2015), Trotta et al. (2011), van } \\
\text { Loon, Wijnhoven et al. (2015), Williamson (2011), } \\
\text { Zavattaro and Sementelli (2014), Zheng (2013), } \\
\text { Zuiderwijk et al. (2015). }\end{array}$ & T-P-C & $\begin{array}{l}\text { - e-Government } \\
\text { - Open government } \\
\text { - Transparency } \\
\text { - Social media } \\
\text { - Open government } \\
\text { data } \\
\text { - Participation } \\
\text { - Collaboration } \\
\text { - Open data } \\
\text { - TIC }\end{array}$ \\
\hline
\end{tabular}

